\title{
Impact of Outdoor Education Mountaineering Program on Environmental Concern, Increasing Economy and Social Interaction on Mount Artapela Ascent
}

\author{
Dede Iman Suhendra \\ Universitas Galuh Ciamis \\ Ciamis, Indonesia \\ line 4-e-mail address if desired
}

\author{
Ryan Abu Bakar, Amung Ma'mun, Yusuf Hidayat \\ Pendidikan Olahraga Pascasarjana \\ Universitas Pendidikan Indonesia \\ Bandung, Indonesia
}

\begin{abstract}
The purpose of this study is to explore environmental problems in the Upper Citarum River by revealing the impact of the outdoor education program mountaineering program on Mount Artapela on environmental concerns and economic levels. The method used in this study is expose facto. The population is the ecovillage DLH Jabar Environmental member, Sukapura Village, 25 people, business people and transportation in Sukapura village, 30 people, and 65 members and participants of mount Artapela ascenters. The sampling technique used was purposive sampling with a collection of 32 sample people viewed from work and hobbies. The instrument of this study used interviews and GEBS (General ecology Behaviour scale). Data analysis was performed using SPSS 16. Different test results of data analysis showed that mountaineering programs or mountaineering in Artapela had a significant influence on increasing environmental awareness and improving community economics in Sukapura village.
\end{abstract}

Keywords-outdoor education; mountaineering; mount artapela economic level; environmental concern

\section{INTRODUCTION}

One effective way to improve the progress of a region is through tourism. Many types of tourism have been promoted, one of which is a special interest in hiking. Some regions can develop and advance because of the existence of mountains and mountain ascenting activities. One of the areas in East Java, namely Malang Regency, is progressing because one of them is the impact of ascenting Mount Semeru, so that its economic activities become developed and developed. Not only are the managers developing, it is precisely the other people who provide transportation, culinary, lodging and other fields that have the sweet effects of mountain ascenting. The government through its program the Ministry of Rural and Underdeveloped Regions encouraged the progress of the village in order to be independent and develop. By issuing Village Law No. 6 of 2014 chapter 1 General Provisions Article 1 "Empowerment of the Village Community is an effort to develop the independence and welfare of the community by increasing knowledge, attitudes, skills, behaviours, abilities, awareness, and utilizing resources through the establishment of appropriate policies, programs, activities and assistance with the essence of the problem and priority needs of the village community ". In terms of asserting freedom to the village community so that they can innovate and advance economically by making creative efforts by utilizing the potential of natural resources and human resources they have. Sukapura Village, Kec. Kertasari Bandung Regency which has mountainous natural resources through the SULIBRA Organization has been innovating by holding a mountaineering management of Mount Artapela which began in November 2014 and opened the Ascenting Post in April 2015. Mount Artapela has been widely known by mountain ascenters both for the West Java region and national scope. This is done as an effort to maintain the sustainability condition of Mount Artapela as a protected forest area that is under the authority of Perum Perhutani. In forestry law No. 41 of 1999 Chapter 1 General Provisions point 8 affirms "Protected forest is a forest area that has a main function as protection of life support systems to regulate water management, prevent flooding, control erosion, prevent sea water intrusion, and maintain soil fertility." firmly Gunung Artapela is part of the supporting system for the life of the Kertasari community, which functions to regulate community water and maintain soil fertility.

In the Law on Conservation of Natural Resources and Ecosystem No. 5 of 1990 Article 3 emphasizes "Conservation of living natural resources and its ecosystem aims to strive for the realization of the preservation of biological natural resources and the balance of its ecosystem so that it can further support efforts to improve people's welfare and the quality of human life". The article can be assumed that in the management of the environment natural biological resources must pay attention to the balance of the ecosystem, so that it can support the sustainability of the lives of the next generation of society. The condition of the mountain which is concerned with the depletion of natural forests in Mount Artapela, needs a strategic and quality step in order to be able to compensate for community intervention in agriculture which continues to exploit the forest. If this is allowed, it will certainly disrupt the quality of the environment in the Kertasari sub-district going forward and have an impact on the quality of the Citarum river 
in West Java. Mountain ascenting as one of the special interest tourist destinations is an activity that has always experienced an increase in the number of devotees. Mountain ascenting is not just a tour, but also a character-building education especially the character of love for nature and environmental preservation.

The effects of human population growth and increased exploitation of natural resources, not only encourage increased deforestation in the interests of clearing agricultural land and population settlements but also reduce environmental quality $[1,2]$. To improve the environment, the right paradigm is needed so that humans with the environment are wisely placed. This paradigm places the environment as a necessity and humans as the party that needs it [3]. Perception in managing the environment must be supported by various fields of life, one of the most important by education. Good education will guide human behaviour more respecting the environment so as to make the environment a top priority that must be prioritized so that human survival is better [4-6]. When viewed from the situation, the problem of Mount Artapela environment is a manifestation of human harmony with nature itself, the conflict that occurs between humans and nature will have an impact on human losses, in some cases the destruction of nature begins with conflicts between humans themselves [7]. Solutions that are seen as effective in building concern for the environment, namely by bringing together objects with their subjects to establish mutual attachments [8].

Outdoor Education (OE) as a medium of learning in the open is seen as very effective where everyone will be able to feel, seeing directly can even do it themselves, so that the transfer of knowledge based on experience in nature can be felt, translated, developed by himself $[9,10]$. (OE) is one of the learning media for each individual so as to be able to instil a person's soul bond with nature [11,12]. Feelings of connectedness with nature, encourage individuals to have the desire to preserve it. The feeling of admiration for the creator's creation will be a motivation to be able to maintain it, after experiencing a profound experience in interaction with nature $[10,13]$. Humans are creatures of play are instincts given by the Creator, pleasure in playing cannot be eliminated. Feelings cannot be bought with anything, so learning and playing are inseparable things [14]. OE activities themselves involve more factors and physical activities carried out in the field or outdoors. This approach sharpens physical and social activities where a person will do more activities which indirectly involve collaboration between friends and the ability to create. This activity will bring up the process of communication, problem solving, creativity, decision making, mutual understanding, and respect for differences [10]. Mountain ascenting in Sukapura village, Kertasari is indeed a new thing. So that it often makes pros and cons in the community itself, different perspectives become the main problem in a rural perspective. Less familiar with differences and diversity. So, it needs a study that can be accepted theoretically and empirically in the community as a study material in the scope of deliberation to seek consensus. The existence of this writing, in order to deepen the scientific study of mountain ascenting in view of the history, benefits, obstacles and development of Mount Artapela for today and for the future.

\section{MetHOD}

This research uses expos facto research methods. The method used in this research is expose facto. The population is the ecovillage DLH Jabar Environmental Cadre, Sukapura Village, 25 people, business people and transportation in Sukapura village, 30 people, and 65 members and participants of mount Artapela ascenters. Pickup technique the sample used was purposive sampling with a collection of 32 sample people viewed from work and hobbies. The research instrument is environmental concern using the General Ecology Behaviour Scale GEBS [15], an instrument of social interaction using social interaction scales and economic improvement instruments using the Grow domestic Product (GDP). Data analysis was carried out based on different tests using the SPSS 16 program.

\section{RESULT}

In accordance with the formulation of writing in chapter 1 , in this writing will make the impact of Artapela mountain ascenting in the study, namely the study of the Impact on Environmental Concern, the impact on Economic Growth and the impact on social interaction.

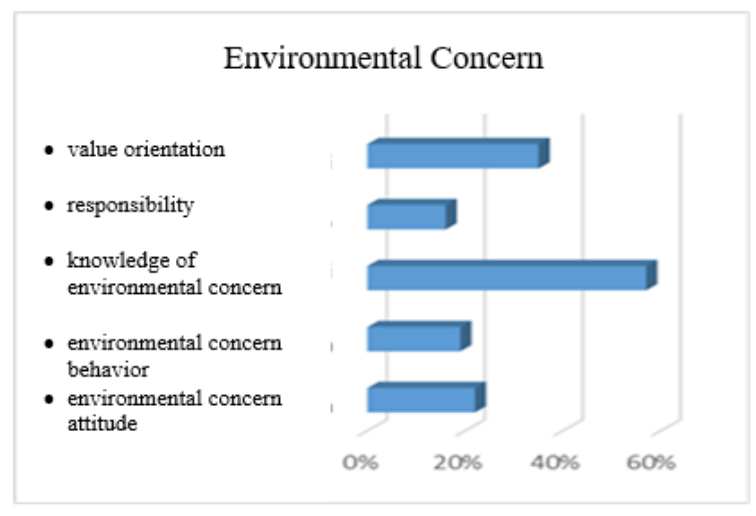

Fig. 1. Impact of Artapela's ascent on environmental concern.

Based on the graph above, it can be seen the concern of the ascenters and the community around Mount Artapela shows the attitude of environmental care $23 \%$, environmental care behaviour 17\%, environmental awareness 55\%, sense of environmental responsibility $14 \%$ and environmental value orientation is $34 \%$. Thus, it can be seen that the environmental concern of the community has an average value of less than $40 \%$. However, this actually experienced an increase from before the existence of the Mount Artapela ascenting post.

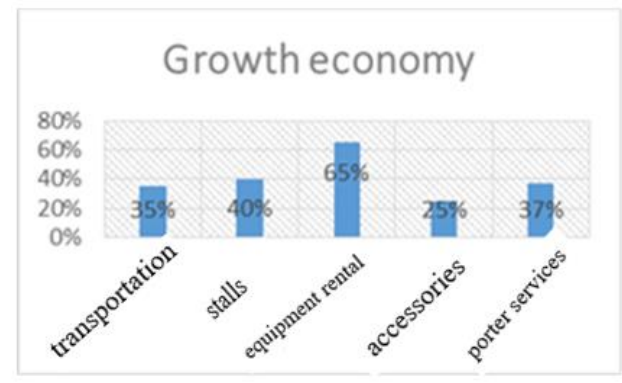

Fig. 2. Impact of mount Artapela's ascent on economic growth. 
Based on the graph above, it can be seen the economic growth of the people involved in Mount Artapela development which shows economic growth in the transportation sector by $35 \%, 40 \%$ stalls, $65 \%$ equipment rental, $25 \%$ accessories, and $37 \%$ porter services.

\section{A. Impact of Artapela Ascent on Social Interaction}

The results of the study of the social interaction of mount Artapela, are divided into 2 types of social interactions namely associative social interaction (positive) and dissociative social interaction (negative). The results show that the impact of the Artapela mountain ascent can be seen in the diagram below:

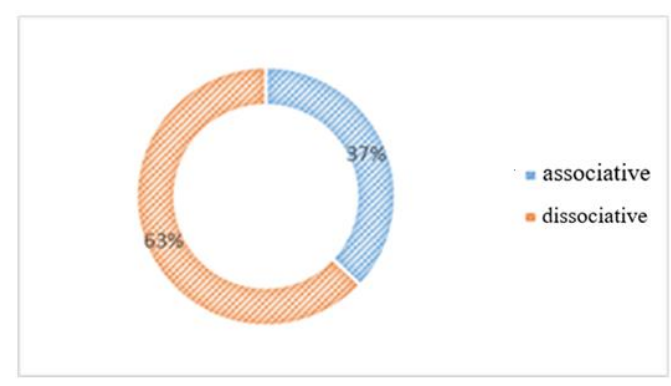

Fig. 3. The impact of the Artapela mountain ascent.

Based on the diagram above it can be seen that the impact of mountaineering on social interactions shows the results of associative social interaction $37 \%$ and dissociative social interactions $67 \%$.

\section{DISCUSSION}

This study uses the expos facto research method, which provides an overview of the impact of mountain ascenting on environmental concerns, improving the economy and social interaction in the mountain area of Artapela. Artapela Mountain is a mountain that was once a dense forest and there are many trees, but over time this region has become barren and changed agricultural land by surrounding communities. A person's environmental concern is an accumulation of one's attitude, the better a person has a higher level of concern for his environment [16]. It could be that environmental damage on Mount Artapela is a wrong attitude from the community in facing life problems, especially in economic pressures.

With the mountaineering, the results of this study indicate an increase in the awareness of the community involved an average of $27 \%$. Increasing environmental awareness is greater in terms of knowledge of environmental concerns, this occurs because of interactions with ascenters who are concerned about environmental concerns and campaigns for nature conservation such as tree planting. But in terms of implementing environmental preservation, it cannot be partial because environmental affairs are a collective problem, so the role of the government as a leader must be more dominant, so that the implementation can be jointly implemented.

The community may not realize that the forest is its natural wealth, because of improper perceptions so that by destroying the forest they assume it will make it rich. But the fact is that forest destruction actually makes it difficult, this makes Kertasari District a Subdistrict that gets the last IPM position in
Bandung Regency. The lack of livelihoods around Artapela made the people darkened their eyes to the point of damaging their own wealth. The existence of the Artapela ascent is an effort to improve the economy of the community without having to damage the forest area, with the mountaineering of Artapela increasing the economy of the people involved an average of $35 \%$. Economic improvement can be seen from the stall owners who become more buyers from ascenters, because every ascenter will prepare his needs while on the mountain buying from the community around the mountain. It also appears in terms of transportation to increase income from both public and public transportation, even to online transportation.

In this study also discusses the impact of mountain ascenting on social interaction. In social interaction on Mount Artapela it is greater for dissociative social interactions than associative social interactions. Responding to new things might lead to many perceptions and assumptions from each person so that they become pros and cons in society. Personal perceptions became the public's perception of the camps as a result of being the pros and cons of Antara which supported and did not support.

\section{CONCLUSION}

The government encourages its people to be economically independent and maintain their environment to be sustainable. Mountain ascenting is a strategic and effective step for the development of a proven area in several regions. In this paper through a study and research shows that mountain ascenting has a big impact on collective economic growth rather than individually, is that not what the State has hoped for so far. Then it turned out that with mountain ascenting it also had a very good impact on increasing environmental awareness, which is currently a massive program to overcome the Citarum problem. However, the lack of attention from the government that cannot be a mediator in the community has finally become a conflict in the community because there is no mediator. Finally, through this paper the author assumes that the mountaineering of Artapela is feasible to be re-established and received attention from the government.

\section{REFERENCES}

[1] M. Caldas, R. Walker, E. Arima, S. Perz, and S. Aldrich, "Land Cover The and Land Use Change: Theorizing Peasant of Amazonian Deforestation Economy," Annals of the American Geographers, vol. 97, no. 1 , pp. 86-110, 2007

[2] W.D. Borrie, "The Growth of the Australian Population with Particular Reference to the Period Since 1947," Population Studies, vol. 13, no. 1, pp. 4-18, 1959.

[3] D. Heyd, "Cultural diversity and biodiversity: a tempting analogy," Critical Review of International Social and Political Philosophy, vol. 13, no. 1, pp. 159-179, 2010.

[4] P.J. Dillon, "Technological education and the environment," International Journal of Science Education, vol. 15, no. 5, pp. 575-589, 1993.

[5] D.W. Orr, "Educating for the Environment," Change, vol. 27, no. 3, p. 43, 1995.

[6] N. Roczen, F.G. Kaiser, F.X. Bogner, and M. Wilson, "A Competence Model for Environmental Education," Environment and Behavior, vol. 46, no. 8, pp. 972-992, 2014. 
[7] G. Curran, "Murray Bookchin and the domination of nature," Critical Review of International Social and Political Philosophy, vol. 2, no. 2, pp. 59-94, 1999.

[8] B. Mansfield, C. Biermann, K. McSweeney, J. Law, C. Gallemore, L. Horner, and D.K. Munroe, "Environmental Politics After Nature: Conflicting Socioecological Futures," Annals of the Association of American Geographers, vol. 105, no. 2, pp. 284-293, 2015.

[9] K. Byrka, T. Hartig, and F.G. Kaiser, "Environmental Attitude As A Mediator Of The Relationship Between Psychological Restoration In Nature And Self-Reported Ecological Behavior 1,2," Psychological Reports, vol. 107, no. 3, pp. 847-859, 2010.

[10] L.G. D'Amato and M.E. Krasny, "Outdoor Adventure Education: Applying Transformative Learning Theory to Understanding Instrumental Learning and Personal Growth in Environmental Education," The Journal of Environmental Education, vol. 42, no. 4, pp. 237-254, 2011.

[11] I.E. Palmberg and J. Kuru, "Outdoor Activities as a Basis for Environmental Responsibility," The Journal of Environmental Education, vol. 31, no. 4, pp. 32-36, 2000.
[12] M. Thorburn, "Moral deliberation and environmental awareness: reviewing Deweyan-informed possibilities for contemporary outdoor learning," Journal of Adventure Education and Outdoor Learning, pp. 110, 2017.

[13] A.K. Liefländer, G. Fröhlich, F.X. Bogner, and P.W. Schultz, "Promoting connectedness with nature through environmental education," Environmental Education Research, vol. 19, no. 3, pp. 370384, 2013.

[14] S.C. Wu, "What Can Chinese and German Children Tell Us About Their Learning and Play in Kindergarten?" Journal of Research in Childhood Education, vol. 29, no. 3, pp. 338-351, 2015.

[15] F.G. Kaiser and M. Wilson, "Goal-directed conservation behavior: The specific composition of a general performance," Personality and Individual Differences, vol. 36, no. 7, pp. 1531-1544, 2004.

[16] A.M. Al-Damkhi, A.M. Khuraibet, S.A. Abdul-Wahab, and F.A.H. AlAttar, "COMMENTARY: Toward Defining the Concept of Environmental Crime on the Basis of Sustainability," Environmental Practice, vol. 11, no. 2, p. 115, 2009. 